Review

\title{
Surface Electrical Potentials of Root Cell Plasma Membranes: Implications for Ion Interactions, Rhizotoxicity, and Uptake
}

\section{Yi-Min Wang ${ }^{1,2}$, Thomas B. Kinraide ${ }^{3}$, Peng Wang ${ }^{4}$, Xiu-Zhen Hao ${ }^{1}$ and Dong-Mei Zhou ${ }^{1, *}$}

1 Key Laboratory of Soil Environment \& Pollution Remediation, Institute of Soil Science, Chinese Academy of Sciences, Nanjing 210008, China; E-Mails: wangym@issas.ac.cn (Y.-M.W.); xzhao@issas.ac.cn (X.-Z.H.)

2 University of Chinese Academy of Sciences, Beijing 100049, China

3 Agricultural Research Service, United States Department of Agriculture, Collaborating Scientist, Plant Science Research Unit, Raleigh, NC 27695, USA; E-Mail: tom@kinraide.net

4 The University of Queensland, School of Agriculture and Food Sciences, St. Lucia, Queensland 4072, Australia; E-Mail: p.wang3@uq.edu.au

* Author to whom correspondence should be addressed; E-Mail: dmzhou@issas.ac.cn; Tel.: +86-25-8688-1180.

External Editor: Bing Yan

Received: 14 September 2014; in revised form: 28 November 2014 / Accepted: 1 December 2014 / Published: 8 December 2014

\begin{abstract}
Many crop plants are exposed to heavy metals and other metals that may intoxicate the crop plants themselves or consumers of the plants. The rhizotoxicity of heavy metals is influenced strongly by the root cell plasma membrane (PM) surface's electrical potential $\left(\psi_{0}\right)$. The usually negative $\psi_{0}$ is created by negatively charged constituents of the PM. Cations in the rooting medium are attracted to the PM surface and anions are repelled. Addition of ameliorating cations (e.g., $\mathrm{Ca}^{2+}$ and $\mathrm{Mg}^{2+}$ ) to the rooting medium reduces the effectiveness of cationic toxicants (e.g., $\mathrm{Cu}^{2+}$ and $\mathrm{Pb}^{2+}$ ) and increases the effectiveness of anionic toxicants (e.g., $\mathrm{SeO}_{4}{ }^{2-}$ and $\mathrm{H}_{2} \mathrm{AsO}_{4}{ }^{-}$). Root growth responses to ions are better correlated with ion activities at PM surfaces $\left(\left\{I^{Z}\right\}_{0}\right)$ than with activities in the bulk-phase medium $\left(\left\{I^{Z}\right\}_{\mathrm{b}}\right)\left(I^{Z}\right.$ denotes an ion with charge $\left.Z\right)$. Therefore, electrostatic effects play a role in heavy metal toxicity that may exceed the role of site-specific competition between toxicants and ameliorants. Furthermore, $\psi_{0}$ controls the transport of ions across the PM by influencing both $\left\{I^{Z}\right\}_{0}$ and the electrical potential difference across the PM from the outer

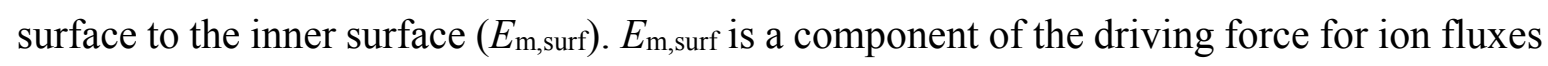


across the PM and controls ion-channel voltage gating. Incorporation of $\left\{I^{Z}\right\}_{0}$ and $E_{\mathrm{m} \text {,surf into }}$ quantitative models for root metal toxicity and uptake improves risk assessments of toxic metals in the environment. These risk assessments will improve further with future research on the application of electrostatic theory to heavy metal phytotoxicity in natural soils and aquatic environments.

Keywords: plasma membrane; surface electrical potential; heavy metal; rhizotoxicity; metal uptake; risk assessment

\section{Introduction}

Contamination of the environment by heavy metals and other intoxicating metals has been studied for many years because of the ubiquity and bioavailability of such metals [1]. Although metals such as $\mathrm{Cu}, \mathrm{Zn}, \mathrm{Mn}, \mathrm{Mo}, \mathrm{Ni}$, and $\mathrm{Co}$ are essential for plants and animals, some of these metals are well known to be toxic to organisms when present in excessive concentrations [2]. For many years environmentalists have considered the chemical, physiological, and toxicological characteristics of heavy metals in risk assessments and in the formulation of regulatory criteria [3]. However these procedures still focus on the total or free-metal ion activities, as described by the free-metal ion activity model (FIAM), and sometimes ignore some important environmental factors such as $\mathrm{pH}$ and the concentrations of ameliorative ions such as $\mathrm{Ca}^{2+}$ and $\mathrm{Mg}^{2+}$. Di Toro et al. have emphasized that toxic cations (commonly heavy metals) compete with ameliorative ions for active sites at the cell plasma membrane (PM) surface [4]. This view of site-specific competition has been incorporated into the biotic ligand model (BLM), and the BLM is commonly accepted by scientists and regulators. The BLM has been applied to several different metals and organisms, and the model is still undergoing improvement.

Although the success of the BLM in risk assessments of cationic toxicants has been demonstrated extensively, its inability to evaluate aspects of anionic toxicity has been noted. Specifically, cationic ameliorants such as $\mathrm{Ca}^{2+}$ and $\mathrm{Mg}^{2+}$ alleviate the toxicity of cationic toxicants such as $\mathrm{Cu}^{2+}$ and $\mathrm{Hg}^{2+}$, but these cationic ameliorants enhance the toxicity of anionic toxicants such as $\mathrm{SeO}_{4}{ }^{2-}$ and $\mathrm{H}_{2} \mathrm{AsO}_{4}{ }^{-}$. The latter cannot be interpreted in terms of site-specific competition (i.e., by the BLM). Surely, competition plays a role in the interactions between toxicants and ameliorants, but its role may be small compared to the role played by global (rather than site-specific) electrical potentials at the outer surface of the PM. These variable, but usually negative potentials arise from negatively charged structural components of the PM such as the carboxylic acid groups of acidic amino acids and the phosphate groups of phospholipids [5,6]. These negative charges are the source of the PM surface electrical potential (denoted $\psi_{0}$ ). $\psi_{0}$ affects the distribution of ions between the bulk-phase solution and the PM surface, thereby playing an important role in plant-ion interactions [7]. The addition of common cations, such as $\mathrm{Ca}^{2+}, \mathrm{Mg}^{2+}$, and $\mathrm{H}^{+}$, to the rooting medium reduces $\psi_{0}$ negativity through ion binding and charge screening at the PM [8]. A World-Wide-Web-accessible (Web-accessible) Gouy-Chapman-Stern (GCS) model is now available for the computation of $\psi 0$ and ion activities at PM surfaces [9]. A growing number of studies have employed electrostatic theory and the Gouy-Chapman-Stern model to evaluate plant-ion interactions [9-12]. 
These studies demonstrate the advantage of using PM-surface ion activities $\left(\left\{I^{Z}\right\}_{0}\right.$, where $I^{Z}$ denotes an ion with charge $Z$ ) in the assessment of plant-ion interactions. Responses such as intoxication, alleviation of intoxication, and ion uptake often correlate well with $\left\{I^{Z}\right\}_{0}$ and often correlate poorly with $\left\{I^{Z}\right\}_{\mathrm{b}}$ (ion activities in the bulk-phase rooting medium) (see [13] for extensive tabulations). Kinraide analyzed the mechanisms of $\mathrm{Ca}^{2+}$ alleviation of several ion toxicities, including salinity toxicity, in terms of electrostatic effects. Among these was the $\mathrm{Ca}^{2+}$-induced reduction in the negativity of $\psi_{0}$ and the consequent reduced attraction of cationic toxicants to the PM surface [14]. Kopittke et al. confirmed the advantage of using $\left\{I^{Z}\right\}_{0}$ over $\left\{I^{Z}\right\}_{\mathrm{b}}$ in the assessment of cowpea root responses to $\mathrm{Cu}$ or $\mathrm{Pb}[11]$. Electrostatic effects also proved to be essential for modeling the rhizotoxicity of $\mathrm{SeO}_{4}{ }^{2-}$ and $\mathrm{H}_{2} \mathrm{AsO}_{4}{ }^{-}[15,16]$. As we shall illustrate later, changes in $\psi_{0}$ influence not only the value of $\left\{I^{Z}\right\}_{0}$, they also influence the gradient of electrical potential across the PM from outer surface to inner surface

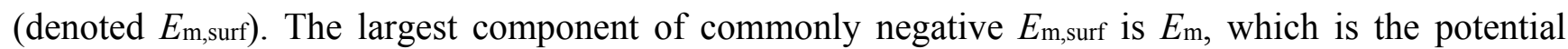
difference between the external cell bathing medium and the cell interior (Figure 1). $E_{\mathrm{m} \text {,surf }}$ is responsible for ion-channel voltage gating and is the principal driving force for ion fluxes across the PM [13,17,18]. Thus, in our review study, we aimed to (1) introduce the basic theory of cell-surface electrostatic effects; (2) specify the role of $\psi_{0}$ in plant responses to heavy metal stress; and (3) consider the prospect of additional use of electrostatic theory in future assessments of organism-ion interactions in natural soil environments.

\section{Basic Theory of Gouy-Chapman-Stern (GCS) Model}

Two search engines (ISI Web of Science and Google Scholar) were used for the acquisition of data from the period 1964-2014. These data were concerned mainly with solution-culture studies of the toxicity and uptake of $\mathrm{Zn}, \mathrm{Cd}, \mathrm{Pb}, \mathrm{Cu}, \mathrm{Co}, \mathrm{Ni}, \mathrm{Al}, \mathrm{SeO}_{4}{ }^{2-}$, and $\mathrm{H}_{2} \mathrm{AsO}_{4}{ }^{-}$. These studies considered electrostatic effects and the influence of different environmental factors, such as $\mathrm{pH}$ and the concentrations of $\mathrm{Ca}, \mathrm{Mg}, \mathrm{Na}$, and $\mathrm{K}$, in modeling responses to toxicants. A variety of species were used in the studies; they included wheat, barley, pea, cowpea, lettuce, Escherichia coli, and phytoplankton.

\subsection{Computation of the Cell-Surface Potential ( $\psi$ o) with a GCS Model}

The Gouy-Chapman-Stern model is composed of Gouy-Chapman theory (a century-old electrostatic theory) and the Stern portion of the model, which incorporates ion binding to the PM surface. This GCS model enables the computation of $\psi_{0}$ and, from that, the ion activities at the PM surface $\left(\left\{I^{Z}\right\}_{0}\right)$. Details of this GCS model can be found in a book chapter [19] and several published papers [7,20,21]. A brief review of the model is presented here.

In the Gouy-Chapman theory, the intrinsic surface charge density $\left(\sigma_{0}\right.$, in units Coulombs per $\left.\mathrm{m}^{2}\right)$ at the PM surface is the total charge density in the absence of ion binding. If the PM surface binding sites (i.e., negatively charged sites $R^{-}$and neutral sites $P^{0}$ ) are occupied by ions, then the actual PM-surface charge density $(\sigma)$ may be expressed by the Grahame Equation:

$$
\sigma^{2}=2 \varepsilon_{r} \varepsilon_{0} R T \sum_{i}\left[I^{Z}\right]_{b}\left(\exp \left[-Z_{i} F \psi_{0} /(R T)\right]-1\right)
$$

where $2{ }^{\varepsilon}{ }_{r}{ }_{0} R T=0.00345$ when concentrations are expressed in $\mathrm{M}$ at $25{ }^{\circ} \mathrm{C}$ ( $\varepsilon$ r is the dielectric constant for water, $\varepsilon_{0}$ is the permittivity of a vacuum, and $F, R$, and $T$ are the Faraday constant, the gas 
constant, and the temperature, respectively ). $\left[I^{Z}\right] \mathrm{b}$ refers to free ion concentrations in the bulk-phase medium, and $Z_{\mathrm{i}}$ is the charge on the $\mathrm{i}$ th ion.

Ion binding (the Stern modification) produces the PM-surface species $R I^{Z^{-1}}$ and $P I^{Z}$, and equilibrium reactions may be written as follows:

$$
\begin{gathered}
R^{-}+I^{Z} \Leftrightarrow R I^{Z-1} K_{R I}=\left[R I^{Z-1}\right] /\left(\left[R^{-}\right]\left[I^{Z}\right]_{0}\right) \\
P^{0}+I^{Z} \Leftrightarrow P I^{Z} \cdot K_{P I}=\left[P I^{Z}\right] /\left(\left[P^{0}\right]\left[I^{Z}\right]_{0}\right)
\end{gathered}
$$

where $\left[R^{-}\right],\left[P^{0}\right],\left[R I^{Z-1}\right]$ and $\left[P I^{Z}\right]$ denote PM surface densities expressed in $\mathrm{mol} \cdot \mathrm{m}^{-2} \cdot\left[I^{Z}\right]_{0}$ denotes the concentration of the unbound ion $I^{Z}$ at the PM surface. Therefore, taking the Stern modification of the Gouy-Chapman theory into consideration, the actual $\sigma$ in Equation (1) can also be expressed as:

$$
\sigma=\left\{-\left[R^{-}\right]+\sum_{i}\left(Z_{i}-1\right)\left[R I^{Z^{-1}}\right]+\sum_{i} Z_{i}\left[P I^{Z}\right]\right\} F
$$

To calculate the values of $\left[I^{Z}\right]_{0}$, a Boltzmann Equation is introduced:

$$
\left[I^{Z}\right]_{0}=\left[I^{Z}\right]_{\mathrm{b}} \exp \left[-Z_{i} F \psi_{0} /(R T)\right]
$$

To compute $\psi_{0}$, trial values (changed incrementally and progressively) are assigned to $\psi_{0}$ in Equations (1) and (5) until the values for $\sigma$ computed in Equations (1) and (4) converge. Of course, one must have values for other parameters such as the equilibrium constants in Equations (2) and (3) and the total surface densities of binding sites $R$ and $P$. These values are available in the Web-accessible GCS model [9]. After that, knowledge of $\psi_{0}$ enables the calculation of ion activities at the PM surface $\left(\left\{I^{Z}\right\}_{0}\right)$ according to the Nernst Equation:

$$
\left\{I^{Z}\right\}_{0}=\left\{I^{Z}\right\}_{\mathrm{b}} \exp \left[-Z_{i} F \psi_{0} /(R T)\right]
$$

where $\left\{I^{Z}\right\}_{\mathrm{b}}$ is the free ion activity of the ith ion in the bulk-phase medium. These values may be obtained from dedicated speciation programs (e.g., Visual Minteq, WHAM, GEOCHEM, or PhreeqcI) and from the Web-accessible GCS model.

\subsection{Data Analysis}

Under heavy metal stress, responses of organisms were recorded and analyzed for toxicity assessment. For plant growth, root growth inhibition was usually used for metal rhizotoxicity assessment. For bacteria, potential nitrification rate and glucose-induced respiration were evaluated [22]. These responses were then incorporated into a modified Weibull Equation. In the equation below, relative root elongation (RRE) in the presence of toxicant is expressed as a percent of root elongation (RE) in the absence of toxicant $\left(R R E=100 R E_{\text {toxicant present }} / R E_{\text {toxicant absent }}\right)$ :

$$
R R E=100 / \exp \left[\left(a\{T\}_{0}\right)^{b}\right]
$$

where $\{T\}_{0}$ is the toxicant intensity (activity in our review) at PM surface. Coefficient $a$ is the strength coefficient and increases with the strength of the toxicant, and $b$ is a shape coefficient. When $b>1$, the plot of $R R E v S$. $\{T\}_{0}$ is downwardly sigmoidal. When $\{T\}_{0}$ is very great, $R R E=0 \%$; when $\{T\}_{0}$ is zero, $R R E=100 \%$. Coefficients $a$ and $b$ are determined by regression analysis of paired values of $R R E$ and $\{T\}_{0}$. 


\section{Application of Cell-Surface Electrical Potential in Studies of Metal Toxicity}

\subsection{The Profile of Electrical Potential across the Cell Surface}

For plant PMs, three global electrical properties account for the plant-metal interactions. Figure 1 illustrates a cell in which the PM and the cell wall $(\mathrm{CW})$ are separated because of mild plasmolysis; that is, the plant tissue is slightly wilted. The gap between the PM and the CW is considered to be filled with an aqueous solution similar to, but not identical to, the external bathing medium. In soil-grown plants, the external bathing medium and the gap solution are grounded naturally, and in experimental work these solutions are usually, but not necessarily, grounded deliberately. The transmembrane electrical potential difference $\left(E_{\mathrm{m}}\right)$ is the electrical potential difference from the bulk solution to the cell interior. $E_{\mathrm{m}}$ is the sum of three potential differences. One of these is the potential difference between the PM outer surface and the external medium $\left(\psi_{0}\right)$. The notation $\psi_{0}$ indicates the potential at zero distance from the PM surface. The curved lines represent the profile of the electrical potential upon approach to the

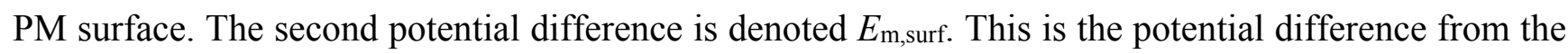
PM exterior surface to the PM interior surface. As a simplification, the profile of $E_{\mathrm{m} \text {,surf }}$ across the PM is depicted as a straight line. The third potential difference $\left(\psi_{0, \text { cyt }}\right)$ is the potential difference between the PM inner surface and the cell cytoplasm. $\psi_{0}$ is responsive to the ionic composition of the bulk medium; $\psi_{0, \text { cyt }} \approx 10 \mathrm{mV}$ and is unresponsive to the ionic composition of the bulk medium. Consequently, $E_{\mathrm{m} \text {,surf is }}$

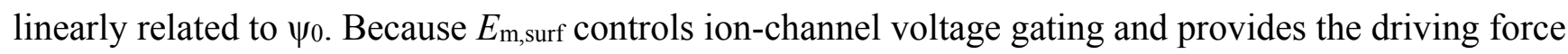
for ion influx across the PM surface, both gating and driving force are effectively controlled by $\psi 0$.

The preceding discussion may be appropriate for mildly plasmolyzed cells or for cell protoplasts from which the $\mathrm{CW}$ has been removed enzymatically. However, in the case of turgid, intact cells, the PM is pressed tightly against the $\mathrm{CW}$. In such cases, it may not be reasonable to assume that the cell may be modeled as though the CWs have no influence upon $\psi_{0}$ and $\left\{I^{Z}\right\}_{0}$. In fact, the structural components of the CWs carry negative charges, and the aqueous solution within the CWs is commonly considered to be in Donnan equilibrium with the external bathing media. Consequently the CW Donnan phase is negatively charged and enriched in free cations and depleted in free anions relative to the external medium. Shomer et al., [23] have computed and measured indirectly the potential of the CW Donnan phase relative to the external medium $(\psi \mathrm{CW})$ and Kinraide [24] has analyzed the possible effect of the CWs upon $\psi_{0}$ and $\left\{I^{Z}\right\}_{0}$ after assuming that the PM surface is bathed in the CW Donnan phase (Model 2) rather than in the external medium (Model 1). Values for $\psi_{0, \text { Model } 1}$ were surprisingly similar to the

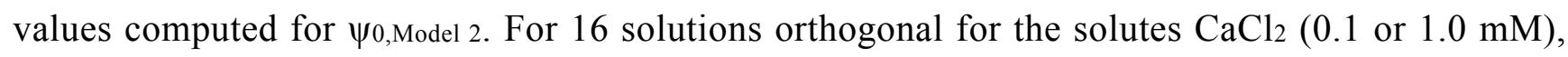
$\mathrm{NaCl}(1$ or $10 \mathrm{mM}), \mathrm{LaCl}_{3}(1$ or $10 \mu \mathrm{M})$, and $\mathrm{H}^{+}\left(\mathrm{pH} 4.6\right.$ or 5.6). $r^{2}=0.989$ for the regression $\psi 0$,Model $1=a+b \psi 0$,Model 2, where coefficient $a=0.001$ and coefficient $b=1.000$ are both significant. To compute ion activities at PM outer surfaces according to Model 1 or Model 2, one incorporates either $\psi_{0, \text { Model } 1}$ and $\left\{I^{Z}\right\}_{\mathrm{b}}$ or $\psi_{0, \text { Model } 2}$ and $\left\{I^{Z}\right\}_{\mathrm{CW}}$ Donnan phase into the Nernst Equation (Equation (6)). The resulting values for $\left\{I^{Z}\right\}_{0, \text { Model } 1}$ and $\left\{I^{Z}\right\}_{0 \text {,Model } 2}$ are as highly correlated as the values for $\psi_{0, \text { Model } 1}$ and $\psi 0$,Model 2. The explanation for these similarities in values is that the placement of CWs against PMs causes multiple offsetting effects, as described in detail in Kinraide [24]. On the basis of these analyses and on the basis of experimental work cited in the study of Kinraide [24], one may compute the electrostatic effects upon toxicity, the alleviation of toxicity, and the uptake of ions on the basis of $\psi_{0}$ 
and $\left\{I^{Z}\right\}_{0}$ computed as though CWs had no effect (Model 1). These criteria can be applied to evaluate heavy metal rhizotoxicity and accumulation in metal-polluted soils.

Figure 1. Schematic diagram of electrical profiles and ion distributions at a plant root cell surface, as described in the text. Cations are denoted by $\mathrm{M}^{z^{+}}$(in red circle), and anions are denoted by $\mathrm{M}^{z^{-}}$(in green circle). $-R^{-}$and $-P^{0}$ denote negatively charged and uncharged membrane components exposed at the outer surface of the plasma membrane (PM). The solid curve represents the profile of electrical potential from the external medium to the inner surface of the PM; The dashed curve illustrates this profile after the addition of surface-depolarizing solutes to the external medium. $E_{\mathrm{m}}$ is the transmembrane electrical potential difference from the bulk solution to the cell interior; $\psi_{0}$ is the potential difference between the PM outer surface and the external medium; $E_{\mathrm{m} \text {,surf }}$ is the potential difference from the plasma membrane exterior surface to the membrane interior; and $\psi 0$,cyt is the potential difference between the PM inner surface and the cell cytoplasm. $\psi 0$ and $E_{\mathrm{m} \text {,surf }}$ are altered, but $\psi 0$,cyt and $E_{\mathrm{m}}$ remain constant.

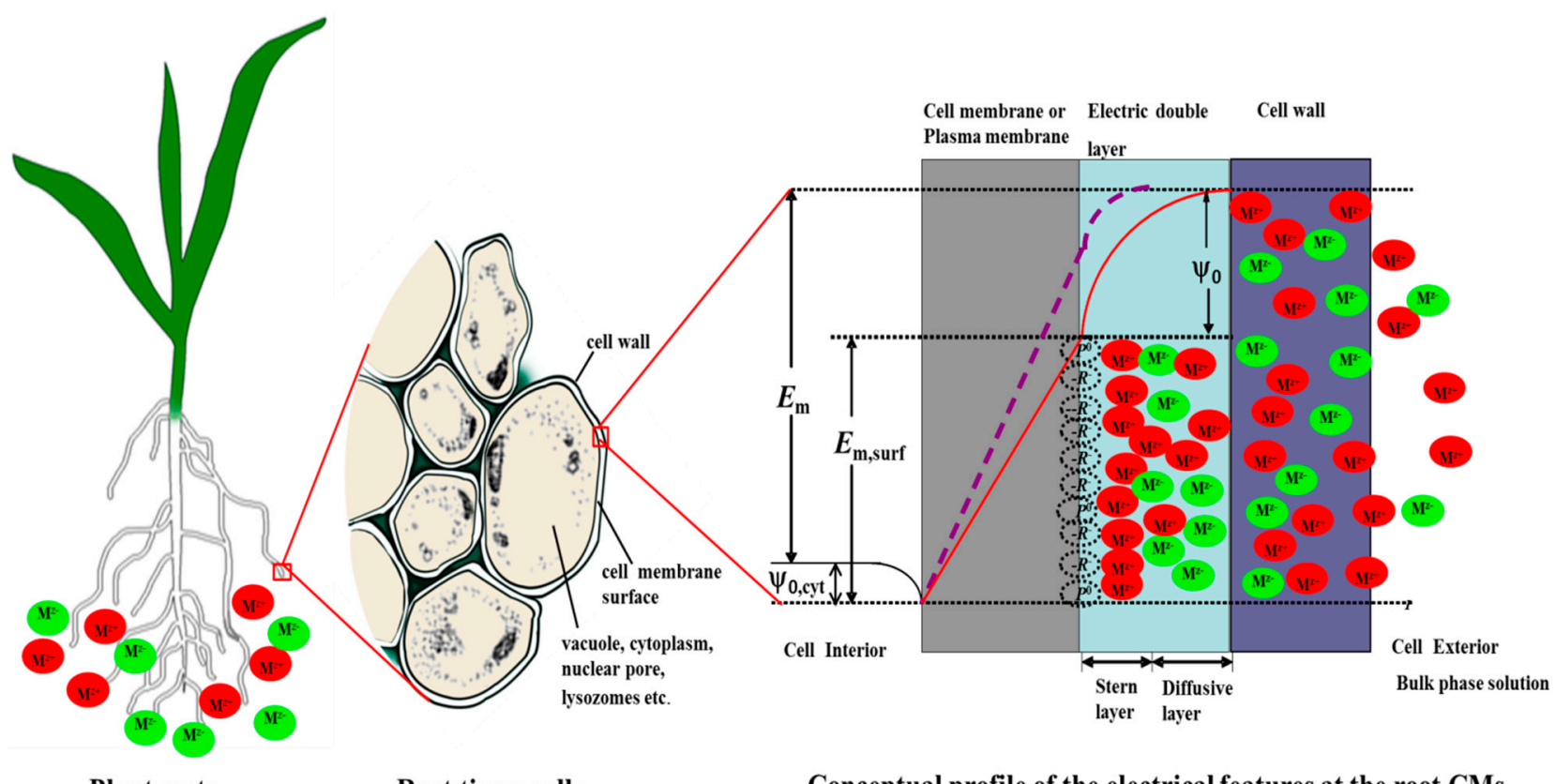

Plant roots

Root tissue cells

Conceptual profile of the electrical features at the root $\mathrm{CMs}$

\subsection{Verification of the Calculated Values of $\psi$, and Some Parameter Values of the GCS Model}

$\psi_{0}$ is difficult to measure, whereas the measurement of $E_{\mathrm{m}}$ is relatively simple. For the latter, measurement entails the insertion of microelectrodes into cells [7,25]. Values for $\psi_{0}$ are commonly computed from $\zeta$ potentials. These are the near-surface electrical potentials measured in electrophoresis experiments. $\zeta$ potentials are well correlated with calculated $\psi_{0}$ values (see Table S1 and see [26]). The calculated $\psi_{0}$ and the measured $\zeta$ potential in different media from previous studies are listed in Table S1. Physiological responses to ionic solutions provide indirect evidence for the accuracy of computed values for $\psi 0$.

As described by the GCS model above, computation of $\psi_{0}$ requires the knowledge of $\sigma_{0}$ (units: Coulombs per $\mathrm{m}^{2}$ ) and the ionic composition of the rooting medium. Kinraide and Wang [26] considered 
$\sigma_{0}$ to be the parameter in greatest doubt, and in a dedicated analysis of published data obtained by different experimental and computational methods concluded that $\sigma_{0}=-30 \mathrm{mC} \cdot \mathrm{m}^{-2}$ is a suitable value for PMs generally, despite small differences obtained from different species and different cultural conditions. Computation of $\psi_{0}$ also requires estimated values for ion binding strength to the negative and neutral binding sites $\left(R^{-}\right.$and $\left.P^{0}\right)$ at the PM surface. Yermiyahu and co-workers $[19,21]$ used ion adsorption experiments to compute binding strengths for 49 ions. Later, Kinraide and Yermiyahu [27] presented "a scale of metal ion binding strengths correlating with ionic charge, Pauling electronegativity, toxicity, and other physiological effects". Eventually, an algorithm to compute the binding strengths of 64 ions was developed [28]. Some of these ions accumulate excessively in agricultural soils.

\subsection{Cationic Toxicants}

Metallic toxicants carrying positive charges are concentrated at the PM surface due to the negative $\psi_{0}$. For instance, when $\psi_{0}=-50.0 \mathrm{mV}$, mono-, di-, and trivalent cations will be concentrated at 7-, 49-, and 343-fold at the PM surface, respectively. These attracted cations reduce the negativity of $\psi_{0}$ through binding and electric screening at the PM surface. The GCS model can compute these changes, and the calculated $\psi_{0}$ values in response to added cations are shown in Figure 2. For example, increasing bulk-phase $\mathrm{Ca}^{2+}$ from 0.23 to $2.50 \mathrm{mM}$ increased (reduced the negativity of) calculated $\psi_{0}$ from -45.6 to $-24.4 \mathrm{mV}$; increasing $\mathrm{K}^{+}$from 0.44 to $29.4 \mathrm{mM}$ increased $\psi_{0}$ from -45.6 to $-32.7 \mathrm{mV}$; and reducing $\mathrm{pH}$ from 7.0 to 4.5 increased $\psi_{0}$ from -45.4 to $-30.4 \mathrm{mV}$. The reduced negativity of $\psi_{0}$ values would reduce the attraction of cationic toxicants at the PM surface, resulting in the alleviation of the cationic metal toxicity. The magnitude of the $\psi_{0}$ increase was strongly dependent on the ion charge and the strength of binding to the PM surface. In a typical growth experiment with variable concentrations of $\mathrm{Zn}$ and other cations, shown in Figure 3, we demonstrated the effectiveness of $\psi_{0}$ in the modeling of rhizotoxicity. When relative root elongation (RRE) was expressed as a function of $\left\{\mathrm{Zn}^{2+}\right\}_{0}$ (Equations (8) and (9)), a better correlation was found $\left(r^{2}=0.745, p<0.0001, n=36\right.$ (Figure 3B)) than when $R R E$ was expressed as a function of $\left\{\mathrm{Zn}^{2+}\right\}_{\mathrm{b}}\left(r^{2}=0.677, p<0.0001, n=36\right.$ (Figure 3A)). Incorporation of both $\left\{\mathrm{Zn}^{2+}\right\}_{0}$ and $\psi_{0}$ into the Weibull Equation (Equation (7) elevated $r^{2}$ to $0.854(p<0.0001, n=36$ (Equation (10), Figure 3C)). Moreover, incorporation of $\left\{\mathrm{Ca}^{2+}\right\}_{0}$ into the model $(p<0.0001, n=36$ (Equation (11), Figure 3D)) further increased the $r^{2}$ to 0.906 . Ca is well known as an essential nutrient in agricultural fields and as an ameliorant. Kinraide [14] proposed three mechanisms by which $\mathrm{Ca}^{2+}$ alleviates the toxicity of $\mathrm{Al}^{3+}, \mathrm{H}^{+}$, and $\mathrm{Na}^{+}$. These mechanisms included (1) reduced cationic toxicant activities at PM surface due to the decreased $\psi_{0}$ negativity by $\mathrm{Ca}$ addition; (2) the restoration of $\mathrm{Ca}^{2+}$ activity at $\mathrm{PM}$ surface if surface $\mathrm{Ca}$ has been reduced to growth-limiting levels by the toxicant; and (3) an assortment of other mechanisms such as the possible competition between $\mathrm{Ca}$ and toxicants at the PM surface or the blocking of the PM channels by $\mathrm{Ca}$ addition [17]. Some polyvalent, strongly binding ions, such as $\mathrm{Al}^{3+}$ and $\mathrm{La}^{3+}$, have a direct effect on $\psi_{0}$ change even if they appear to be channel blockers [17,21]. More studies further demonstrated that intoxication (e.g., reduced root elongation, reduced bacterial nitrification rate, and reduced glucose-induced respiration) can be better explained by the metallic ion activities at the PM surface rather than by ion activities in bulk-phase medium and other electrostatic effects $[11,22]$. 
Figure 2. Responses of root cell plasma membrane (PM) surface electrical potential $\left(\psi_{0}\right)$ to increasing concentrations of $\mathrm{Ca}^{2+}, \mathrm{K}^{+}$, and $\mathrm{H}^{+}$in the cell-bathing media, which contain a background of $0.23 \mathrm{mM} \mathrm{Ca}^{2+}, 0.22 \mathrm{mM} \mathrm{Mg}^{2+}, 0.97 \mathrm{mM} \mathrm{Na}^{+}, 0.44 \mathrm{mM} \mathrm{K}^{+}$and $\mathrm{pH}=6.0$. These $\psi_{0}$ values were calculated by the Gouy-Chapman-Stern (GCS) model. Data were obtained from Wang et al. [29].

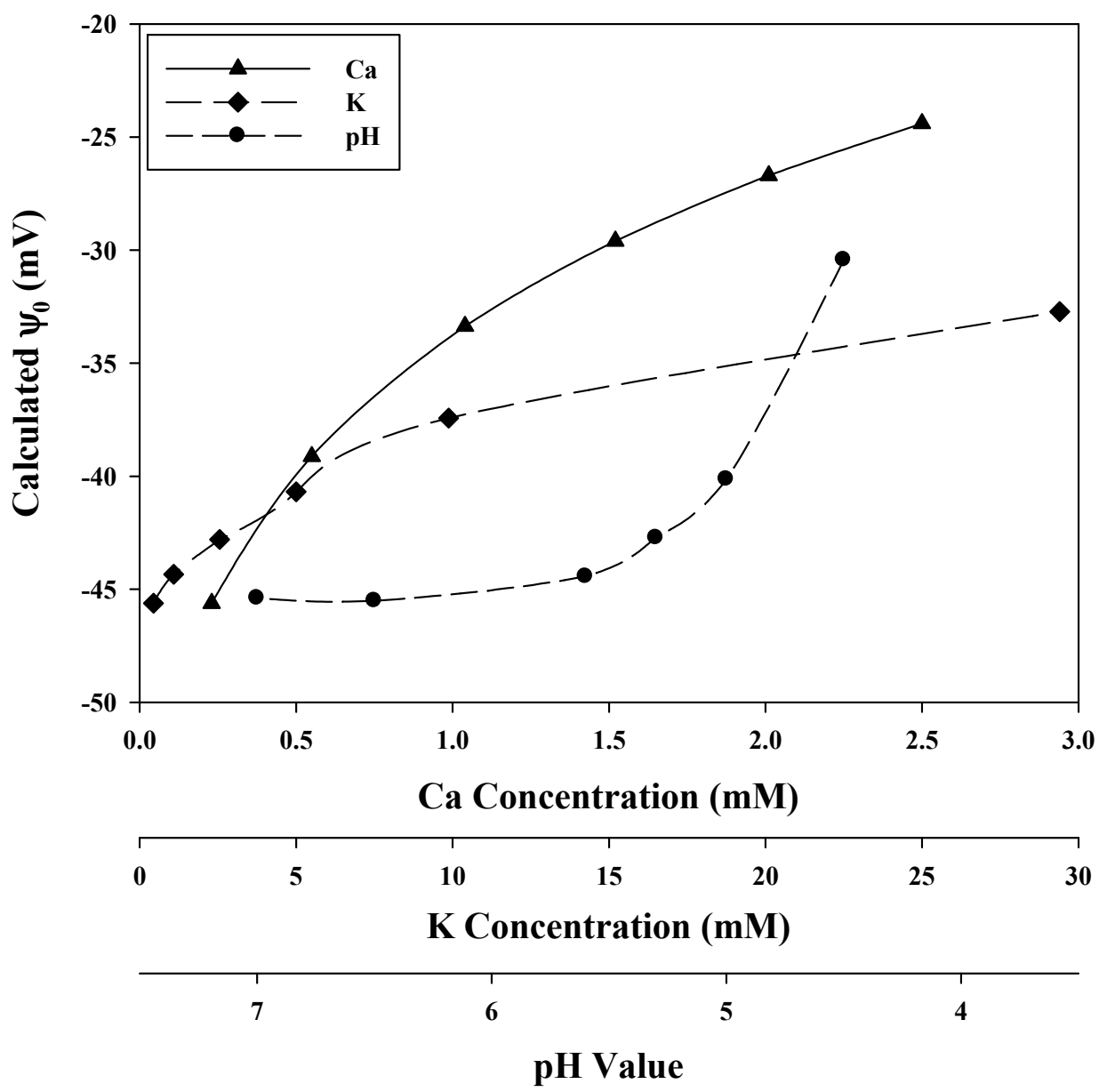

Metal species other than the naked (unhydrolyzed, uncomplexed) free metal ions may be toxic. Wagatsuma and Ezoe [30] showed that the $\mathrm{pH}$ of the medium controls both the identity of the Al species and the toxicity of $\mathrm{Al}$ and argued that hydroxo-Al polymer ions are more toxic to plant roots than mononuclear Al ions. Studies by Parker et al. [31] confirmed that the polynuclear hydroxo-Al $\left(\mathrm{Al}_{13}\right)$ complex was at least 10 -fold more rhizotoxic than $\mathrm{Al}^{3+}$ to wheat seedlings. Possibly due to ion binding strengths at the PM surface, the rhizotoxicity of $\mathrm{Al}$ species to wheat roots follows the order: $\mathrm{Al}_{13}>\mathrm{Al}^{3+}>$ $\mathrm{AlF}^{2+}>\mathrm{AlF}_{2}^{+}$[32]. Wang et al. [33], determined that when the $\mathrm{pH}$ values of the nutrient solutions ranged from 4.50 to $8.25, \mathrm{Cu}^{2+}$ and $\mathrm{CuCO}_{3}$ both contributed to the inhibition of wheat root growth, which was well modeled by taking these species' activities at the PM surface into consideration.

Intracellular metal uptake entails ion diffusion to and accumulation at the PM surface followed by influx of the ion across the PM, sometimes through transporters such as those for $\mathrm{Cu}$ [34]. Both surface

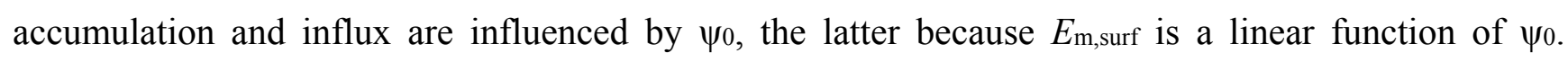
As illustrated in Figure 4, using $\left\{\mathrm{Cu}^{2+}\right\}_{0}$ in the traditional Michaelis-Menten Equation for metal uptake modeling resulted in a higher correlation $\left(r^{2}=0.900, p<0.0001, n=30\right.$ (Equation (13), Figure 4B)) 
than using $\left\{\mathrm{Cu}^{2+}\right\}_{\mathrm{b}}\left(r^{2}=0.853, p<0.0001, n=30\right.$ (Equation (12), Figure 4A)). Moreover, incorporation of both $\left\{\mathrm{Cu}^{2+}\right\}_{0}$ and $\psi_{0}$ into the Michaelis-Menten Equation demonstrates the dual roles of $\psi_{0}$ on metal internalization, and significantly increased $r^{2}$ from 0.853 to $0.963(p<0.0001, n=30$ (Equation (14), Figure 4C)). Detailed descriptions of the dual effects of $\psi_{0}$ on metal ion uptake and toxicity are presented in Kinraide [17] and Wang et al. [13]. Thus, an electrostatic uptake model was developed to incorporate both $\psi_{0}$ and surface ion activities for ion uptake [13].

Figure 3. Relative root elongation (RRE, \%) for wheat seedlings in response to $\mathrm{Zn}^{2+}$ treatments under different $\mathrm{pH}$ values $(4.5,5.5$, and 6.1$)$ or $\mathrm{Ca}^{2+}$ concentrations $(0.05,0.1$, and $0.5 \mathrm{mM})$. Metal ion activities were expressed as ion activities in bulk-phase solutions $\left(\left\{\mathrm{Zn}^{2+}\right\} \mathrm{b}\right)$ or activities at the PM surface $\left(\left\{\mathrm{Zn}^{2+}\right\}_{0}\right)$. The equation $R R E=100 / \exp \left[\left(a\left\{\mathrm{Zn}^{2+}\right\} \mathrm{b}\right)^{b}\right]$ (Equation (8)) was used in (A); $R R E=100 / \exp \left[\left(a\left\{\mathrm{Zn}^{2+}\right\} 0\right)^{b}\right]$ (Equation (9)) was used in (B); $R R E=100 / \exp \left[\left(a\left(1+c \psi_{0}\right)\left\{\mathrm{Zn}^{2+}\right\}_{0}\right)^{b}\right]$ (Equation (10)) was used in (C); and $R R E=$ $100\left\{1-1 / \exp \left(p\left\{\mathrm{Ca}^{2+}\right\}_{0}\right)\right\} / \exp \left[\left(a\left(1+c \psi_{0}\right)\left\{\mathrm{Zn}^{2+}\right\}_{0}\right)^{b}\right]$ (Equation (11)) was used in (D). The dashed line in (D) shows the 1:1 slope relationship. Data were obtained from Wang et al. [12,35].

(A)

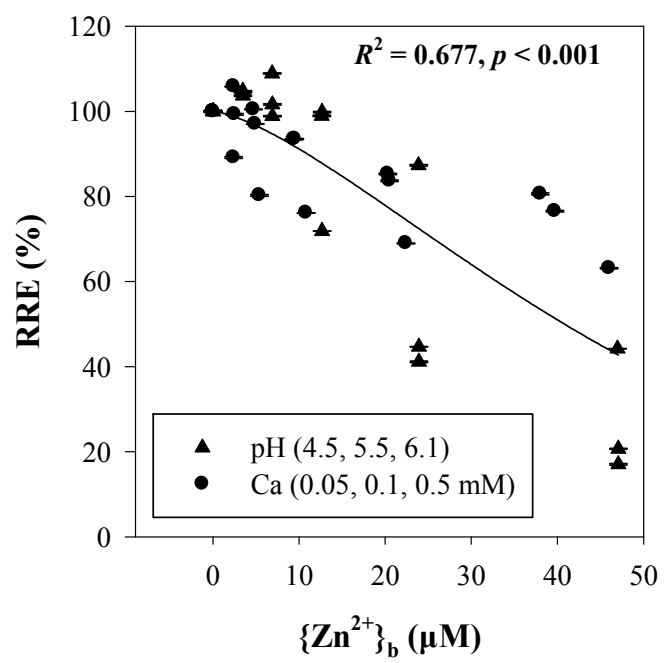

(C)

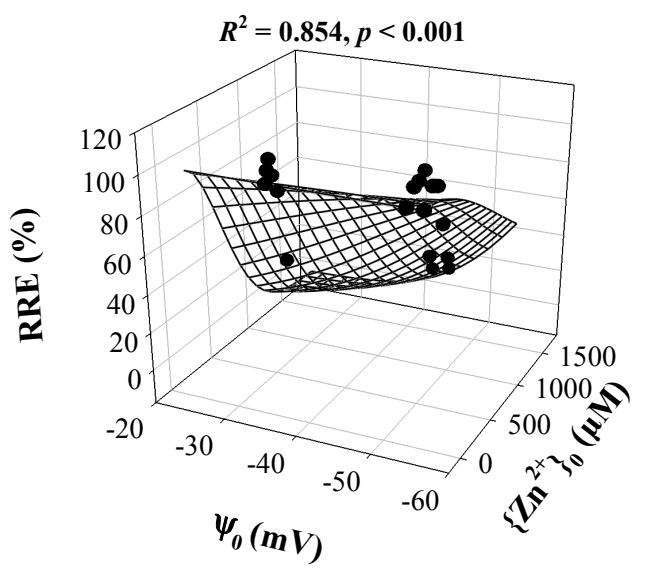

(B)

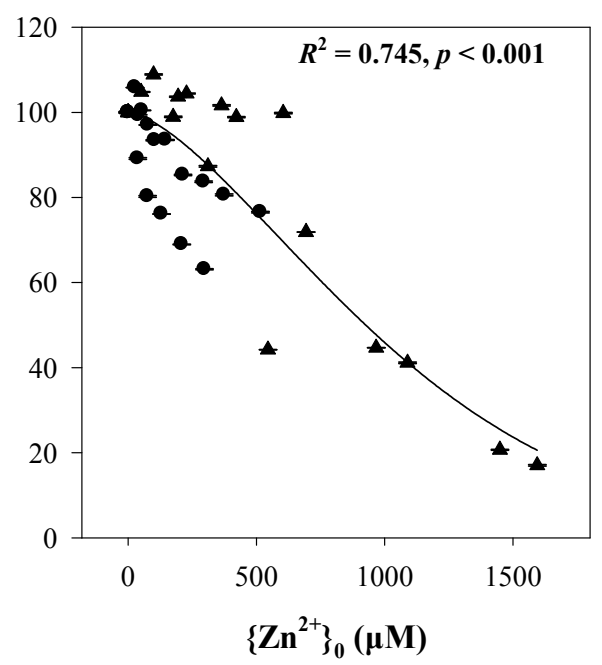

(D)

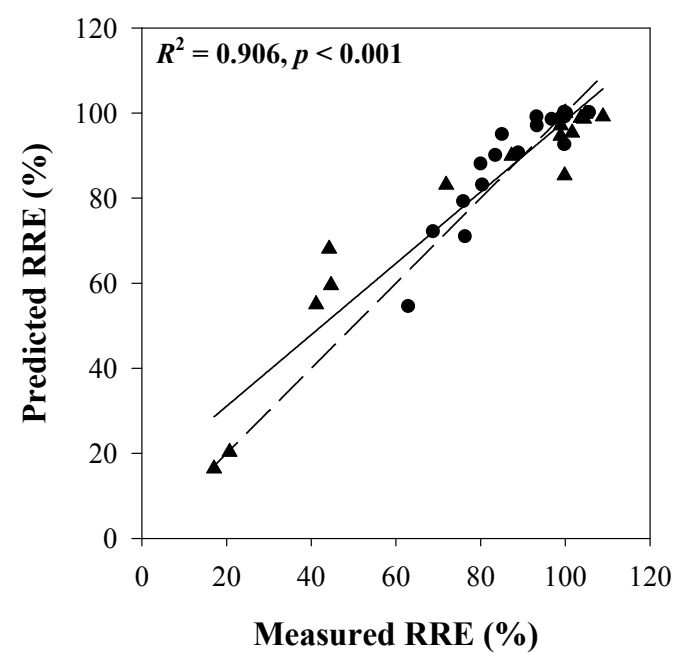


Figure 4. Metal accumulation in wheat seedling roots in response to $\mathrm{Cu}^{2+}$ treatments under different values for $\mathrm{pH}(5.1,5.5$, and 6.0) and Ca concentration $(0.25,1.0$, and $4.0 \mathrm{mM})$. Metal ion activities were expressed as ion activities in bulk-phase solutions $\left(\left\{\mathrm{Cu}^{2+}\right\} \mathrm{b}\right)$ or activities at the PM surface $\left(\left\{\mathrm{Cu}^{2+}\right\} 0\right)$. The Michaelis-Menten Equation $\mathrm{Cu}$ uptake = $a\left\{\mathrm{Cu}^{2+}\right\} \mathrm{b} /\left(K_{\mathrm{m}}+\left\{\mathrm{Cu}^{2+}\right\}_{\mathrm{b}}\right)$ (Equation (12)) was used in (A); Cu uptake $=a\left\{\mathrm{Cu}^{2+}\right\}_{0} /$ $\left(K_{\mathrm{m}}+\left\{\mathrm{Cu}^{2+}\right\}_{0}\right)$ (Equation (13)) was used in (B); and $\mathrm{Cu}$ uptake $=a\left(1+b \psi_{0}\right)\left\{\mathrm{Cu}^{2+}\right\}_{0} /$ $\left(K_{\mathrm{m}}+\left\{\mathrm{Cu}^{2+}\right\}_{0}\right)$ (Equation (14)) was used in (C). Data were obtained from Wang et al. [13].

(A)

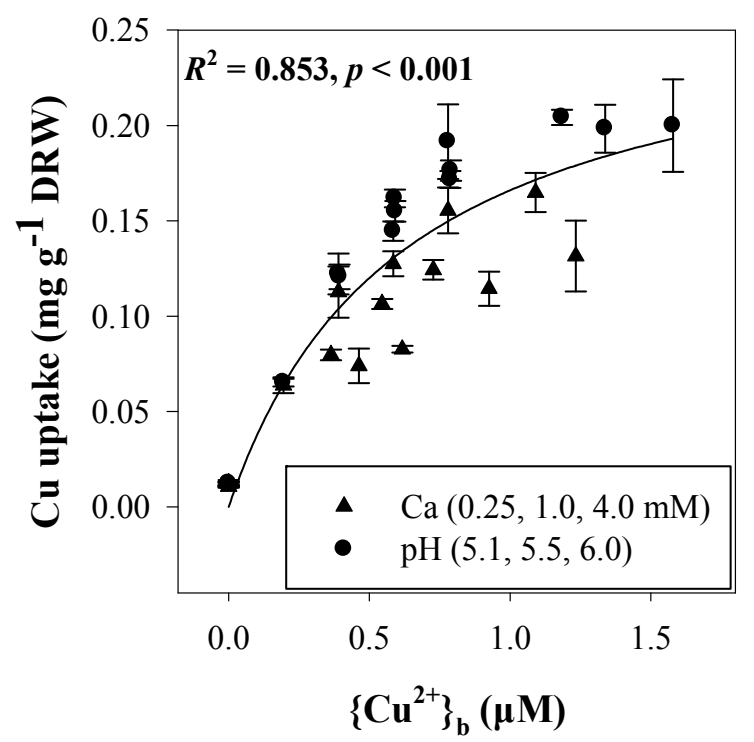

(B)

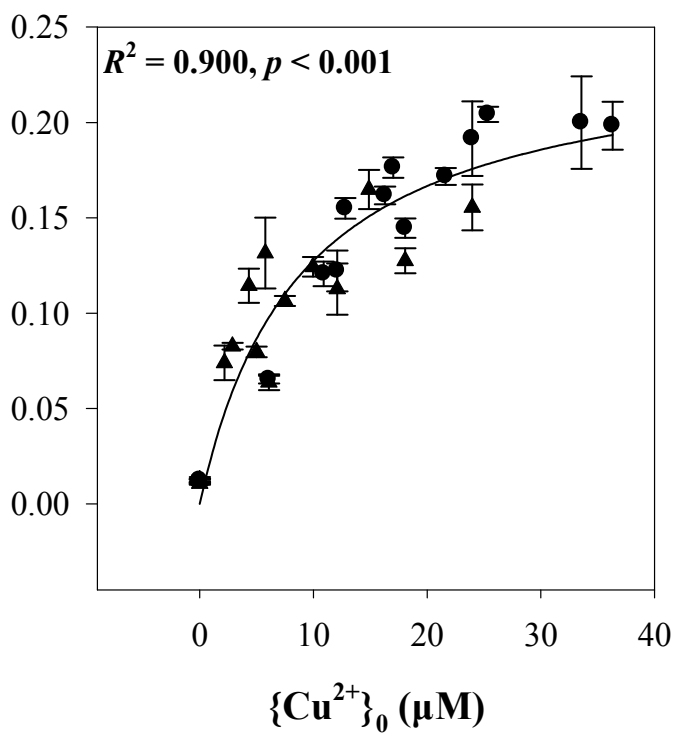

(C)

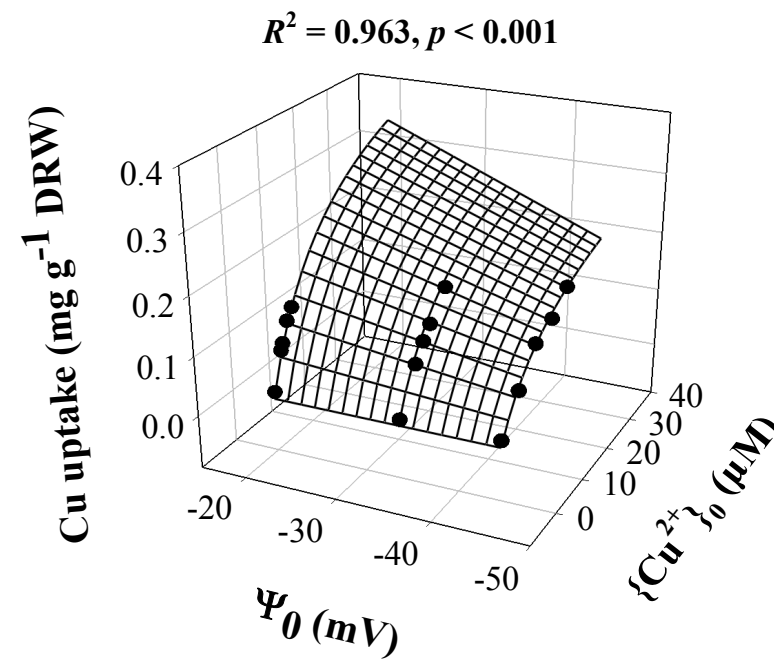

\subsection{Anionic Toxicants}

In contrast to the extensive studies of cationic toxicants, anionic toxicants have been little studied in terms of toxicity modelling. As mentioned in the Introduction, the BLM model fails to assess anionic metalloid bioavailability. Due to the dominance of anionic forms in many metalloids, Kinraide and co-workers $[15,16]$ introduced $\psi_{0}$ into the interpretation and modeling of anionic toxicants, in particular $\mathrm{SeO}_{4}^{-}$, and $\mathrm{H}_{2} \mathrm{AsO}_{4}{ }^{-}$. 
In Figure 5, we see that when $\left\{\mathrm{Ca}^{2+}\right\} \mathrm{b}$ was increased from 0 to $4.32 \mathrm{mM}$, $\psi_{0}$ increased from -52.1 to $-19.3 \mathrm{mV}$. The reduced negativity of $\psi_{0}$ concentrated $\left\{\mathrm{H}_{2} \mathrm{AsO}_{4}{ }^{-}\right\}_{0}$ from 0.11 to $0.35 \mu \mathrm{M}$ when the test solutions contained $1 \mu \mathrm{M} \mathrm{NaH} 2 \mathrm{AsO}_{4}$. This resulted in the enhancement of the $\mathrm{As}(\mathrm{V})$ rhizotoxicity. In Figure 6 we present wheat seedling root growth and root metal uptake in response to $\mathrm{H}_{2} \mathrm{AsO}_{4}{ }^{-}$. Under different $\mathrm{pH}$ levels in the test solutions, $R R E$ was better correlated with $\{\mathrm{As}(\mathrm{V})\}_{0}\left(r^{2}=0.964, p<0.0001\right.$, $n=25$ (Figure 6B, Equation (16))) than with $\{\mathrm{As}(\mathrm{V})\}_{\mathrm{b}}\left(r^{2}=0.880, p<0.0001, n=25\right.$ (Figure 6A, Equation (15))). Traditional ion competition for binding sites could not provide a reasonable explanation of toxicity, but the PM surface activities of $\mathrm{As}(\mathrm{V})\left(\{\mathrm{As}(\mathrm{V})\}_{0}\right)$ well interpreted the results of $\mathrm{As}(\mathrm{V})$ toxicity. In modeling the $\mathrm{As}(\mathrm{V})$ root uptake, we also found that substitution of $\{\operatorname{As}(\mathrm{V})\}_{0}$ for $\{\operatorname{As}(\mathrm{V})\}_{\mathrm{b}}$ improved the prediction of uptake from an $r^{2}$ of $0.762(p<0.0001, n=18$ (Figure 6C, Equation (17))) to an $r^{2}$ of 0.843 (Figure 6D, $p<0.0001, n=18$ (Equation (18))). Related results have been reported by Kinraide [15], who detected an enhancement of $\mathrm{SeO}_{4}{ }^{-}$rhizotoxicity from decreases in $\mathrm{pH}$ or from additions of $\mathrm{CaCl}_{2}, \mathrm{MgCl}_{2}$, or $\mathrm{SrCl}_{2}$.

Despite the superiority of using $\psi_{0}$ in the evaluation of metalloid rhizotoxicity, we should keep in mind that some metalloid species are uncharged. In some cases, ion-specific interactions at PM, such as channel blockade, more than the global electrostatic effect, may play important roles in toxicity and its alleviation. Therefore, efforts to clarify additional mechanisms and to improve models should continue in future studies [36].

Figure 5. The calculated $\mathrm{PM}$ surface activities of $\mathrm{H}_{2} \mathrm{AsO}_{4}{ }^{-}\left(\left\{\mathrm{H}_{2} \mathrm{AsO}_{4}{ }^{-}\right\}_{0}\right)$ at $1.0 \mu \mathrm{M}$ $\mathrm{NaH}_{2} \mathrm{AsO}_{4}$, and the calculated PM surface electrical potential $\left(\psi_{0}\right)$ in response to different $\mathrm{Ca}^{2+}$ activities $\left(\left\{\mathrm{Ca}^{2+}\right\} \mathrm{b}\right)$ in test solutions, which contain a background of $0.27 \mathrm{mM} \mathrm{Ca}^{2+}$, $0.26 \mathrm{mM} \mathrm{Mg}^{2+}, 1.26 \mathrm{mM} \mathrm{Na}^{+}$, and $0.52 \mathrm{mM} \mathrm{K}^{+}$at $\mathrm{pH}$ 6.0.

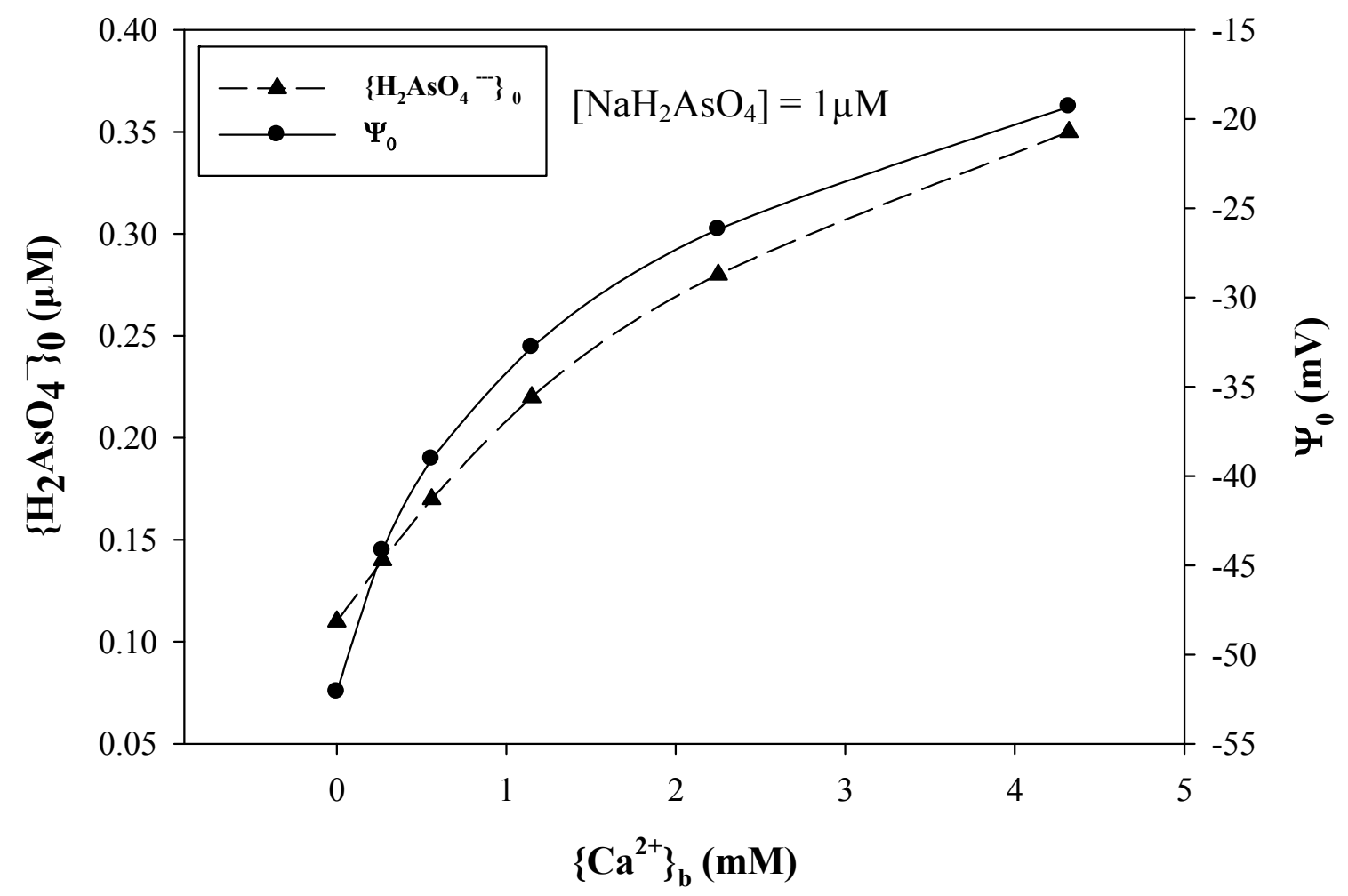


Figure 6. Relative root elongation (RRE, \%) and root metal accumulation in wheat seedlings in response to $\mathrm{NaH}_{2} \mathrm{AsO}_{4}$ treatments under different $\mathrm{pH}$ and $\mathrm{Mg}$ levels. Ion activities were expressed as activities in the bulk-phase solutions $\left(\{\mathrm{As}(\mathrm{V})\}_{\mathrm{b}}\right)$ and at the PM surface $\left(\{\operatorname{As}(\mathrm{V})\}_{0}\right)$. The Weibull Equation RRE $=100 / \exp \left[(a\{\operatorname{As}(\mathrm{V})\} \mathrm{b})^{b}\right]$ (Equation (15)) was used in (A); and the Equation RRE $=100 / \exp \left[\left(a\{\mathrm{As}(\mathrm{V})\}_{0}\right)^{b}\right]$ (Equation (16)) was used in (B); The Michaelis-Menten equation as Uptake $=a\{\operatorname{As}(\mathrm{V})\}_{\mathrm{b}} /\left(K_{\mathrm{m}}+\{\mathrm{As}(\mathrm{V})\}_{\mathrm{b}}\right)$ (Equation (17)) was used in (C); and the equation as Uptake $=a\{\mathrm{As}(\mathrm{V})\}_{0} /\left(K_{\mathrm{m}}+\{\mathrm{As}(\mathrm{V})\}_{0}\right)$ (Equation (18)) was used in (D). Data were obtained from Wang et al. $[13,29]$.

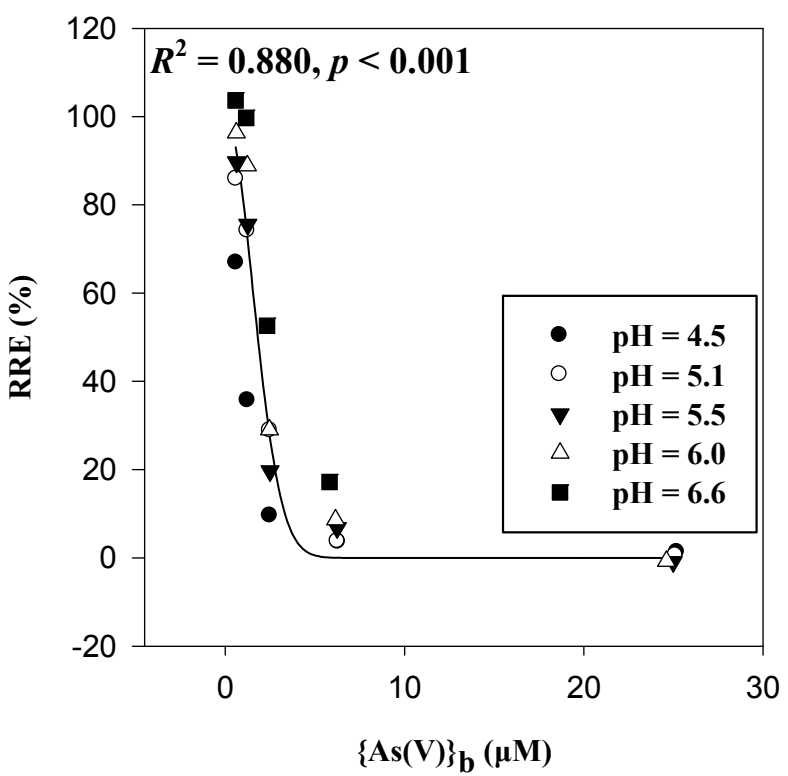

(A)

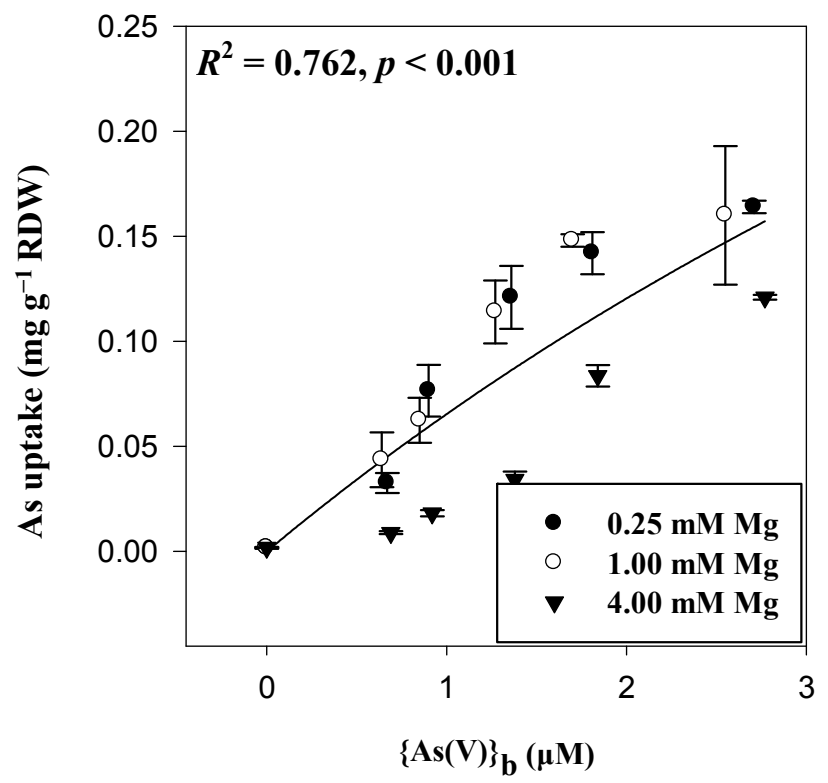

(C)

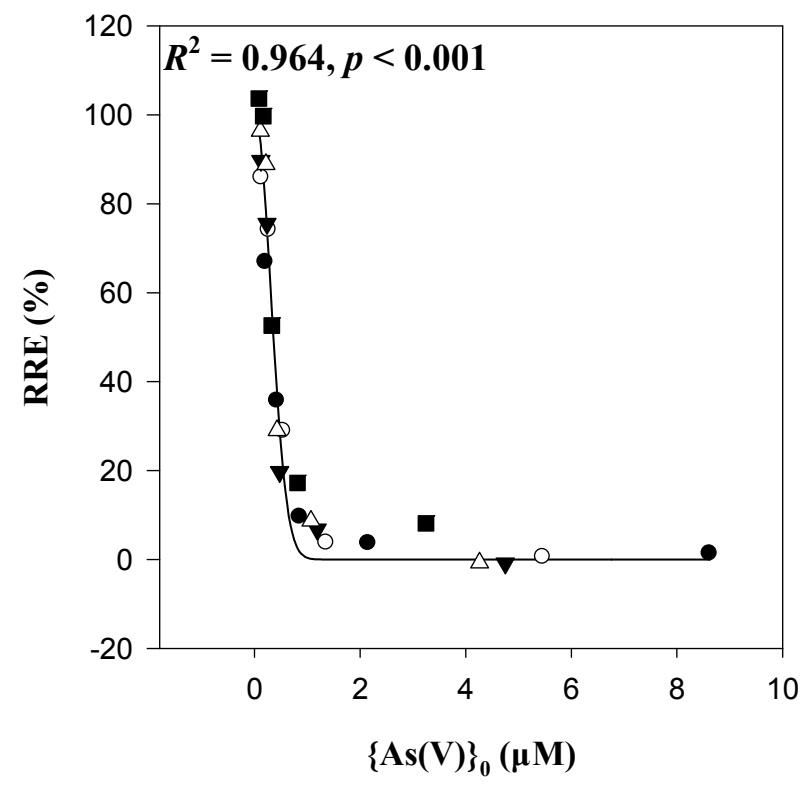

(B)

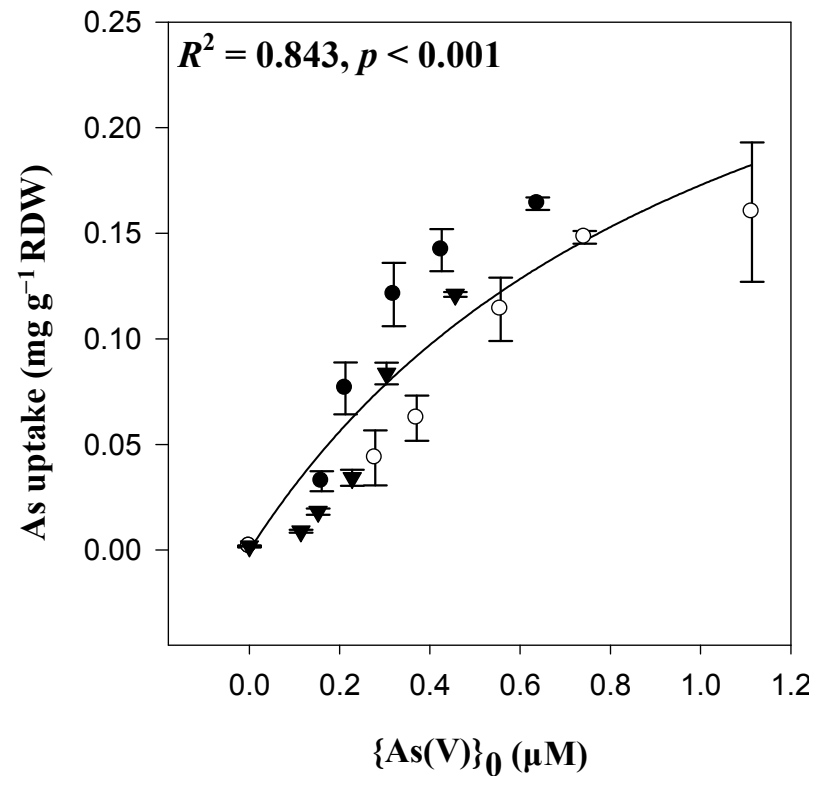

(D) 


\section{Ongoing Use of Electrostatic Principles in Risk Assessment and Modeling}

For decades, $\psi_{0}$ has used extensively to assess the effects of single toxicants in the environment. However, environmental management should be based on the risk assessment of multiple metal toxicants in many cases. In natural environments, organism exposure to metal mixtures has been reported broadly. For example, An et al., reported that when cucumber (Cucumis sativus) was exposed to $\mathrm{Cu}-\mathrm{Cd}$ mixtures, $\mathrm{Cu}$ accumulation in shoots was inhibited by $\mathrm{Cd}$ [37]. Cui et al., investigated human urine and blood as indicators of health after exposure to $\mathrm{Cd}-\mathrm{Pb}$ mixtures in Nanning (China). The results showed that the mixtures caused significant renal dysfunction in the residents [38]. Moreover, studies of multiple metal toxicity in soil invertebrates (earthworms, nematodes, etc.) and microorganisms (Escherichia coli, Pseudomonas fluorescens, etc.) have been reported [39,40].

Currently, joint action assessments of multiple metals are commonly based on the traditional TU (toxic unit) concept combined with the CA (concentration addition) or IA (independent action) models. Vijver et al., showed that metal combinations, antagonistic and synergistic effects are usually observed in toxic-metal analyses [41,42]. Therefore, the essential scientific challenge is to further develop the traditional models for responses to multiple metals. Le et al., [43] introduced the traditional CA concept into the BLM model and successfully evaluated the effect of binary mixtures of $\mathrm{Cu}-\mathrm{Ag}$ and $\mathrm{Cu}-\mathrm{Zn}$ toxicity on lettuce, Lactuca sativa. However, these studies of metal mixtures are still based on free metal ion activities or concentrations in the external media rather than metal activities at PM surfaces. In Figure 7, we present wheat seedling root growth in response to $\mathrm{Zn}$-Co mixtures. Considering ion interactions among $\mathrm{Zn}^{2+}, \mathrm{Co}^{2+}$, and $\mathrm{H}^{+}$at the PM surface enhanced the prediction ability $\left(r^{2}\right)$ from $0.655(p<0.0001$, $n=108$ (Figure 7, Equation (19) in Table S2)) to $0.895(p<0.0001, n=108$ (Figure 7, Equation (20) in Table S2)), based on an extended multiplicative model. Details of the correlations are shown in Table S2. Kinraide [44], in a study of salinity toxicity, used a multiplicative model to quantitatively assess the multiple toxic and ameliorative effects of PM surface activities of $\mathrm{Ca}^{2+}, \mathrm{Na}^{+}$and $\mathrm{K}^{+}$. Hence, we should recognize the potency of $\psi_{0}$ for the assessment of multi-metal toxicity in the environment $[12,35]$.

Furthermore, environmental risk evaluation is a difficult task in the natural soil environment due to the complexity of soil properties. Previous studies have principally used plants grown in solution culture. Developed methods for collecting soil solutions and calculating metal speciation in soil solutions (e.g., programs such as WHAM-humic software and the GCS program) have enabled the application of electrostatic principles in soil environmental risk assessment. Wang et al. [45] applied an electrostatic toxicity model (ETM) for modeling $\mathrm{Ni}^{2+}$ toxicity to barley root growth in soils. The results indicated that root elongation was well correlated with the $\left\{\mathrm{Ni}^{2+}\right\}_{0},\left\{\mathrm{Ca}^{2+}\right\}_{0},\left\{\mathrm{Mg}^{2+}\right\}_{0}$, and the osmotic effects of soil solutions. Thus, the developed ETM model has the potential to assess the risk of metal toxicity in terrestrial ecosystems. Soil microorganisms (e.g., Escherichia coli and rhizobia) and soil invertebrates (e.g., earthworms) also face heavy metal stresses. Wang et al., [22] established parameters in the GCS model for Escherichia coli, and showed that both $\psi_{0}$ and metal ion activities $\left(\left\{\mathrm{Cu}^{2+}\right\}_{0}\right.$ and $\left.\left\{\mathrm{Ni}^{2+}\right\}_{0}\right)$ at the outer surfaces of bacterial cell membranes influenced the variation in potential nitrification rate (PNR) and the glucose-induced respiration (GIR). Therefore, we conclude that electrostatic effects must be taken into account in the evaluation of metal environmental risk in soil ecosystems and that ongoing research should continue to improve the electrostatic approach. 
Figure 7. Comparison of the measured (A) and predicted (B) root length (RL) when wheat seedlings were exposed to Zn-Co mixtures. Predicted RL was based upon extended multiplicative models using ion activities at PM surfaces $\left(\left\{\mathrm{Zn}^{2+}\right\}_{0}\right.$ and $\left.\left\{\mathrm{Co}^{2+}\right\}_{0}\right)$. The solid lines show the linear regression. The details of the coefficients $c$ and $e$ (Equation (19)) and the function $f\left(\left\{\mathrm{H}^{+}\right\}_{0},\left\{\mathrm{Zn}^{2+}\right\}_{0},\left\{\mathrm{Co}^{2+}\right\}_{0}\right)$ (Equation (20)) are described in Table S2. Data were obtained from Wang et al. [12].

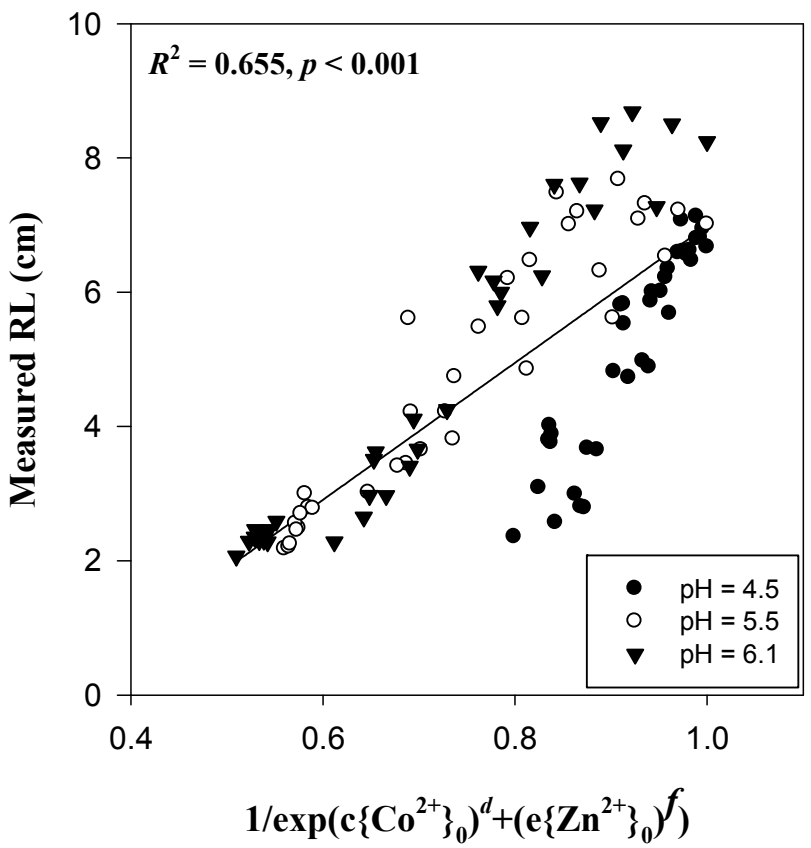

(A)

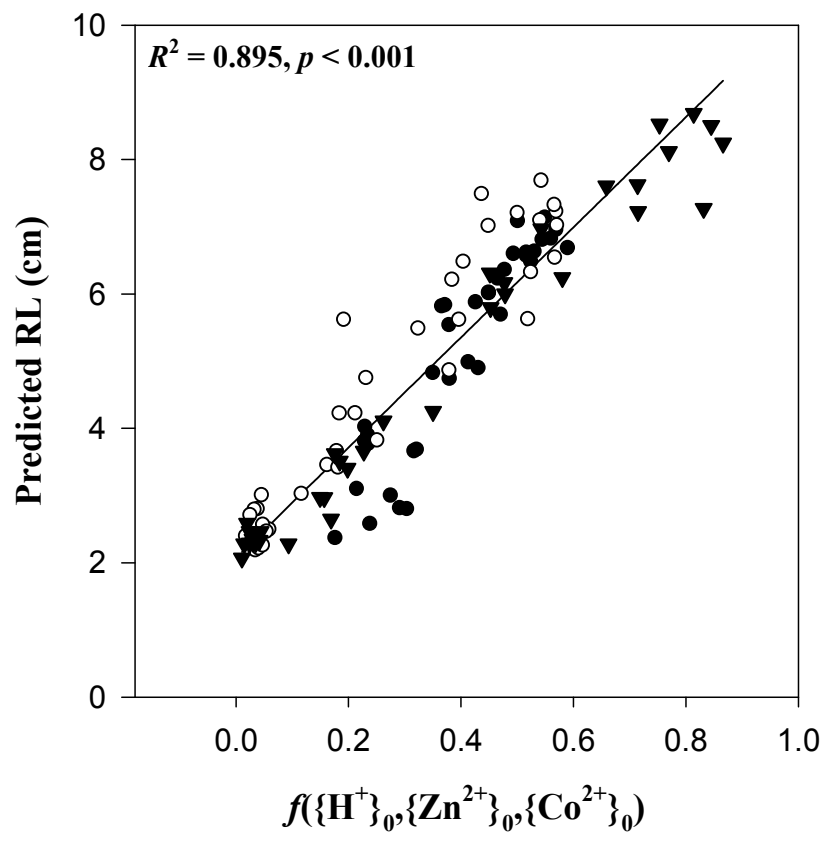

(B)

\section{Supplementary Materials}

Supplementary tables can be found at http://www.mdpi.com/1422-0067/15/12/22661/s1.

\section{Acknowledgments}

This work was supported financially by the National Natural Science Foundation of China (31172034; 41125007)

\section{Author Contributions}

Yi-Min Wang and Dong-Mei Zhou are in charge of data collection and re-analysis, organizing and writing the paper; Thomas B. Kinraide wrote part of the paper and provided valuable revision suggestions; Peng Wang provided the data and provided valuable revision suggestions; and Xiu-Zhen Hao contributed to paper organization and results discussion.

\section{Conflicts of Interest}

The authors declare no conflict of interest. 


\section{References}

1. Nagajyoti, P.; Lee, K.; Sreekanth, T. Heavy metals, occurrence and toxicity for plants: A review. Environ. Chem. Lett. 2010, 8, 199-216.

2. Adriano, D.C. Trace Elements in Terrestrial Environments: Biogeochemistry, Bioavailability, and Risks of Metals; Springer: Berlin, Germany, 2001.

3. Paquin, P.R.; Gorsuch, J.W.; Apte, S.; Batley, G.E.; Bowles, K.C.; Campbell, P.G.; Delos, C.G.; di Toro, D.M.; Dwyer, R.L.; Galvez, F. The biotic ligand model: A historical overview. Comp. Biochem. Physiol. Part C 2002, 133, 3-35.

4. Di Toro, D.M.; Allen, H.E.; Bergman, H.L.; Meyer, J.S.; Paquin, P.R.; Santore, R.C. Biotic ligand model of the acute toxicity of metals. 1. Technical basis. Environ. Toxicol. Chem. 2001, 20, 2383-2396.

5. Lau, A.; McLaughlin, A.; McLaughlin, S. The adsorption of divalent cations to phosphatidylglycerol bilayer membranes. BBA Biomembr. 1981, 645, 279-292.

6. McLaughlin, S. The electrostatic properties of membranes. Annu. Rev. Biophys. Biophys. Chem. 1989, 18, 113-136.

7. Kinraide, T.B.; Yermiyahu, U.; Rytwo, G. Computation of surface electrical potentials of plant cell membranes correspondence to published $\zeta$ potentials from diverse plant sources. Plant Physiol. 1998, 118, 505-512.

8. Kinraide, T.B.; Ryan, P.R.; Kochian, L.V. Interactive effects of $\mathrm{Al}^{3+}, \mathrm{H}^{+}$, and other cations on root elongation considered in terms of cell-surface electrical potential. Plant Physiol. 1992, 99, 1461-1468.

9. Kopittke, P.M.; Wang, P.; Menzies, N.W.; Naidu, R.; Kinraide, T.B. A web-accessible computer program for calculating electrical potentials and ion activities at cell-membrane surfaces. Plant Soil 2014, 375, 35-46.

10. Kobayashi, Y.; Kobayashi, Y.; Watanabe, T.; Shaff, J.E.; Ohta, H.; Kochian, L.V.; Wagatsuma, T.; Kinraide, T.B.; Koyama, H. Molecular and physiological analysis of $\mathrm{Al}^{3+}$ and $\mathrm{H}^{+}$rhizotoxicities at moderately acidic conditions. Plant Physiol. 2013, 163, 180-192.

11. Kopittke, P.M.; Kinraide, T.B.; Wang, P.; Blamey, F.P.C.; Reichman, S.M.; Menzies, N.W. Alleviation of $\mathrm{Cu}$ and $\mathrm{Pb}$ rhizotoxicities in cowpea (Vigna unguiculata) as related to ion activities at root-cell plasma membrane surface. Environ. Sci. Technol. 2011, 45, 4966-4973.

12. Wang, Y.-M.; Kinraide, T.B.; Wang, P.; Zhou, D.-M.; Hao, X.-Z. Modeling rhizotoxicity and uptake of $\mathrm{Zn}$ and Co singly and in binary mixture in wheat in terms of the cell membrane surface electrical potential. Environ. Sci. Technol. 2013, 47, 2831-2838.

13. Wang, P.; Kinraide, T.B.; Zhou, D.; Kopittke, P.M.; Peijnenburg, W.J. Plasma membrane surface potential: Dual effects upon ion uptake and toxicity. Plant Physiol. 2011, 155, 808-820.

14. Kinraide, T.B. Three mechanisms for the calcium alleviation of mineral toxicities. Plant Physiol. 1998, 118, 513-520.

15. Kinraide, T.B. The controlling influence of cell-surface electrical potential on the uptake and toxicity of selenate $\left(\mathrm{SeO}_{4}{ }^{2-}\right)$. Physiol. Plant 2003, 117, 64-71.

16. Wang, P.; Zhou, D.; Weng, N.; Wang, D.; Peijnenburg, W.J. Calcium and magnesium enhance arsenate rhizotoxicity and uptake in Triticum aestivum. Environ. Toxicol. Chem. 2011, 30, 1642-1648. 
17. Kinraide, T.B. Ion fluxes considered in terms of membrane-surface electrical potentials. Funct. Plant Biol. 2001, 28, 607-618.

18. Hille, B. Ion Channels of Excitable Membranes; Sinauer Associates, Inc.: Sunderland, MA, USA, 2001.

19. Yermiyahu, U.; Kinraide, T.; Huang, P.; Gobran, G. Binding and electrostatic attraction of trace elements to plant root surfaces. In Biogeochemistry of Trace Elements in the Rhizosphere; Elsevier: Amsterdam, The Netherlands 2005; pp. 365-389.

20. Kinraide, T.B. Use of a Gouy-Chapman-Stern model for membrane-surface electrical potential to interpret some features of mineral rhizotoxicity. Plant Physiol. 1994, 106, 1583-1592.

21. Yermiyahu, U.; Rytwo, G.; Brauer, D.; Kinraide, T. Binding and electrostatic attraction of lanthanum $\left(\mathrm{La}^{3+}\right)$ and aluminum $\left(\mathrm{Al}^{3+}\right)$ to wheat root plasma membranes. J. Membr. Biol. 1997, 159, 239-252.

22. Wang, P.; Kinraide, T.B.; Smolders, E.; Zhou, D.-M.; Menzies, N.W.; Thakali, S.; Xia, W.-W.; Hao, X.-Z.; Peijnenburg, W.J.; Kopittke, P.M. An electrostatic model predicting $\mathrm{Cu}$ and Ni toxicity to microbial processes in soils. Soil Biol. Biochem. 2013, 57, 720-730.

23. Shomer, I.; Novacky, A.J.; Pike, S.M.; Yermiyahu, U.; Kinraide, T.B. Electrical potentials of plant cell walls in response to the ionic environment. Plant Physiol. 2003, 133, 411-422.

24. Kinraide, T.B. Possible influence of cell walls upon ion concentrations at plasma membrane surfaces. Toward a comprehensive view of cell-surface electrical effects upon ion uptake, intoxication, and amelioration. Plant Physiol. 2004, 136, 3804-3813.

25. Nobel, P. Physicochemical and Environmental Plant Physiology; Academic Press: San Diego, CA, USA, 1991.

26. Kinraide, T.B.; Wang, P. The surface charge density of plant cell membranes $(\sigma)$ : An attempt to resolve conflicting values for intrinsic $\sigma . J$. Exp. Bot. 2010, doi:10.1093/jxb/erq082.

27. Kinraide, T.B.; Yermiyahu, U. A scale of metal ion binding strengths correlating with ionic charge, Pauling electronegativity, toxicity, and other physiological effects. J. Inorg. Biochem. 2007, 101, 1201-1213.

28. Kinraide, T.B. Improved scales for metal ion softness and toxicity. Environ. Toxicol. Chem. 2009, $28,525-533$.

29. Wang, P.; Zhou, D.; Kinraide, T.B.; Luo, X.; Li, L.; Li, D.; Zhang, H. Cell membrane surface potential $\left(\psi_{0}\right)$ plays a dominant role in the phytotoxicity of copper and arsenate. Plant Physiol. 2008, $148,2134-2143$.

30. Wagatsuma, T.; Ezoe, Y. Effect of $\mathrm{pH}$ on ionic species of aluminum in medium and on aluminum toxicity under solution culture. Soil Sci. Plant Nutr. 1985, 31, 547-561.

31. Parker, D.; Zelazny, L.; Kinraide, T. On the phytotoxicity of polynuclear hydroxy-aluminum complexes. Soil Sci. Soc. Am. J. 1989, 53, 789-796.

32. Kinraide, T.B. Reconsidering the rhizotoxicity of hydroxyl, sulphate, and fluoride complexes of aluminium. J. Exp. Bot. 1997, 48, 1115-1124.

33. Wang, P.; Menzies, N.W.; Wang, Y.-M.; Zhou, D.-M.; Zhao, F.-J.; Kopittke, P.M. Identifying the species of copper that are toxic to plant roots in alkaline nutrient solutions. Plant Soil 2012, 361, $317-327$. 
34. Kobayashi, Y.; Kuroda, K.; Kimura, K.; Southron-Francis, J.L.; Furuzawa, A.; Kimura, K.; Iuchi, S.; Kobayashi, M.; Taylor, G.J.; Koyama, H. Amino acid polymorphisms in strictly conserved domains of a P-type ATPase HMA5 are involved in the mechanism of copper tolerance variation in Arabidopsis. Plant Physiol. 2008, 148, 969-980.

35. Wang, Y.-M.; Wang, P.; Ni, L.-F.; Hao, X.-Z.; Zhou, D.-M. Assessment of the Zn-Co mixtures rhizotoxicity under $\mathrm{Ca}$ deficiency: Using two conventional mixture models based on the cell membrane surface potential. Chemosphere 2014, 112, 232-239.

36. Jahn, T.P.; Bienert, G.P. MIPS and Their Role in the Exchange of Metalloids; Springer: Berlin, Germany, 2010.

37. An, Y.-J.; Kim, Y.-M.; Kwon, T.-I.; Jeong, S.-W. Combined effect of copper, cadmium, and lead upon (Cucumis sativus) growth and bioaccumulation. Sci. Total Environ. 2004, 326, 85-93.

38. Cui, Y.; Zhu, Y.-G.; Zhai, R.; Huang, Y.; Qiu, Y.; Liang, J. Exposure to metal mixtures and human health impacts in a contaminated area in Nanning, China. Environ. Int. 2005, 31, 784-790.

39. Qiu, H.; Vijver, M.G.; Peijnenburg, W.J. Interactions of cadmium and zinc impact their toxicity to the earthworm Aporrectodea caliginosa. Environ. Toxicol. Chem. 2011, 30, 2084-2093.

40. Kong, I.C. Joint effects of heavy metal binary mixtures on seed germination, root and shoot growth, bacterial bioluminescence, and gene mutation. J. Environ. Sci. 2013, 25, 889-894.

41. Vijver, M.G.; Elliott, E.G.; Peijnenburg, W.J.; de Snoo, G.R. Response predictions for organisms water-exposed to metal mixtures: A meta-analysis. Environ. Toxicol. Chem. 2011, 30, 1482-1487.

42. Vijver, M.G.; Peijnenburg, W.J.; de Snoo, G.R. Toxicological mixture models are based on inadequate assumptions. Environ. Sci. Technol. 2010, 44, 4841-4842.

43. Yen Le, T.T.; Vijver, M.G.; Jan Hendriks, A.; Peijnenburg, W.J. Modeling toxicity of binary metal mixtures $\left(\mathrm{Cu}^{2+}-\mathrm{Ag}^{+}, \mathrm{Cu}^{2+}-\mathrm{Zn}^{2+}\right)$ to lettuce, Lactuca sativa, with the biotic ligand model. Environ. Toxicol. Chem. 2013, 32, 137-143.

44. Kinraide, T.B. Interactions among $\mathrm{Ca}^{2+}, \mathrm{Na}^{+}$and $\mathrm{K}^{+}$in salinity toxicity: Quantitative resolution of multiple toxic and ameliorative effects. J. Exp. Bot. 1999, 50, 1495-1505.

45. Wang, P.; Kopittke, P.M.; de Schamphelaere, K.A.; Zhao, F.J.; Zhou, D.M.; Lock, K.; Ma, Y.B.; Peijnenburg, W.J.; McGrath, S.P. Evaluation of an electrostatic toxicity model for predicting $\mathrm{Ni}^{2+}$ toxicity to barley root elongation in hydroponic cultures and in soils. New Phytol. 2011, 192, 414-427.

(C) 2014 by the authors; licensee MDPI, Basel, Switzerland. This article is an open access article distributed under the terms and conditions of the Creative Commons Attribution license (http://creativecommons.org/licenses/by/4.0/). 